\title{
Generic Skills for Hospitality Management: A Comparative Study of Management Expectations and Student Perceptions
}

\author{
Mike Raybould \\ and Hugh Wilkins \\ Griffith University, Australia
}

\begin{abstract}
Tertiary providers of hospitality management degree programs must fulfil the needs of student, industry and academic stakeholder groups. The students attracted to this type of program tend to be motivated primarily by the anticipated vocational outcomes. As a result, hospitality management curriculum needs to meet both industry and student expectations by delivering the skill sets needed in the workplace and the institutional demands for academic rigour. This article reports on research that aimed to compare hospitality managers' expectations of graduate skills with student perceptions of the skills that hospitality managers valued. In contrast to previous research on this topic, this study adopted a generic skills framework and managers rated skills associated with interpersonal, problem-solving, and self-management skill domains as most important. Although students tended to rate conceptual and analytical skills more highly than did managers, overall their perceptions of the skills that hospitality managers valued when recruiting graduates were realistic. The results of this, and similar studies, can contribute to curriculum design and the internal and external communications strategies adopted by faculty offering hospitality management programs.
\end{abstract}

Since its inception in the 1920s, there has been considerable growth in hotel and hospitality management education at universities worldwide. However, there has been no change over time in the role of vocational degree programs, including those in hotel and hospitality management, that aim to satisfy an industry need for skilled future employees. As a result, there is a need to ensure the graduates not only meet educational expectations, but also industry expectations regarding the skill sets needed in the workplace. Students enrolling in degree programs in

\section{Correspondence}

Dr Mike Raybould, Department of Tourism, Leisure, Hotel and Sport Management, Griffith Business School, Griffith University, PMB 50 Gold Coast Mail Centre, QLD 9726, Australia. E-mail: m.raybould@griffith.edu.au hotel or hospitality management are motivated by anticipated vocational and career outcomes (O'Mahony, McWilliams, \& Whitelaw, 2001; Purcell \& Quinn, 1996). Thus there is a commonality of interest among educators, industry and students in the currency of workplace skills. This research investigated hospitality managers' expectations of graduate skills and compared these with students' perceptions of the skills that hospitality managers valued. The results of this research are valuable in curriculum development and planning internal and external communications strategies for faculty offering similar courses.

Tertiary educators in hospitality have long recognised the importance of matching program outcomes with industry 
needs and there have been a number of studies of hospitality employer expectations of graduates in the United States (US; for recent examples see Kay \& Russette, 2000; Nelson \& Dopson, 1999; Perdue, Woods, \& Ninemeier, 2000) and in the United Kingdom (UK; Baum, 1991). However, there has been little published in the Asia Pacific region and previous studies have generally adopted the management competency framework developed by Sandwith (1993). This is arguably of limited value in curriculum design as it describes a narrow range of relatively advanced management skills that one would not expect to find in an undergraduate or recent graduate. Instead this study adopts the broader generic skills model, which was developed in an educational context to aid curriculum design (Dunne, Bennett, \& Carre, 1999).

\section{Literature Review}

A number of studies have investigated industry expectations of graduates, graduates' actual skill levels and broader issues related to the hospitality curriculum. This review of the literature is structured under four related themes. It starts by considering the changing needs of industry, the skills that graduates need to commence a career in hospitality management and the role of the hospitality curriculum in developing those skills. It concludes with an overview of the generic skills model that was adopted as the underlying framework for the current research.

\section{Changing Needs of Industry}

Hospitality, like many other industries, has experienced increasing levels of competition and complexity over the last 25 years (Kandampully \& Suhartanto, 2000) and the skills needed by managers in the industry reflect these changes (Chung, 2000). It has been argued that the changes in industry have increased the need for a leadership management style, rather than a supervision and control management style (Umbriet,
1993). There have been few studies of hospitality management style but the literature has reflected the changing role of managers with recognition of the decreasing importance of operational and technical skills (Tas, LaBrecque, \& Clayton, 1996) and a corresponding increase in the emphasis on corporate and strategic skills (Gilbert \& Guerrier, 1997).

Given the changes highlighted by Gilbert and Guerrier (1997) in the role of management in the hospitality industry over the last three decades, it is essential that education providers have a clear understanding of industry and employer expectations of the skills that graduates should have on completion of a degree program. Additionally, research needs to be undertaken regularly to update knowledge of expectations in a dynamic business environment (Perdue et al., 2000).

\section{What Skills Do Graduates Need?}

Research into graduate skill needs has focused on management expectations and has been criticised for ignoring graduate perceptions (Christou, 2000). Studies that have included graduates (Knutson \& Patton, 1992; Okeiyi, Finley, \& Postel, 1994) found that graduates rated human resource skills and liaising with guests as most important. Since many of the studies of management expectations have also identified interpersonal skills as a key area of importance (for examples see O'Halloran, 1992; Nelson \& Dopson, 1999; Tas LaBrecque \& Clayton, 1996; Umbriet, 1992) the student perceptions seem realistic.

Studies of industry expectations of the competencies highlight the fact that hospitality graduates need a range of competencies to perform adequately (Tas, 1988) and the skill expectations are consistent across most studies. There is recognition of the tension between the theoretical and practical aspects of the academic curriculum and, whilst industry has recognised the importance and 
benefits of a theoretical framework (Gilbert \& Guerrier, 1997), they were also critical of the length of time graduates needed to adapt to a workplace role (Whitston, 1998). Industry representatives have also been critical of graduates' unrealistic expectations of the demands of hospitality management as a career (Brotherton, 1993, as cited in Purcell \& Quinn, 1996; Whitston, 1998).

Surveys of industry managers have generally shown that they believe management skills are more important in the university academic curriculum than technical skills and there is consensus on the importance of the broad interpersonal competencies (Okeiyi et al., 1994; Tas, 1988; Umbreit, 1993). Baum (1990) has also suggested that these competencies will be more operationally focused in smaller hotels due to the hands-on management approach needed. The studies have highlighted the importance of human relations, customer relations and motivation skill (Okeiyi et al., 1994), employee relations and managerial skills (Kriegl, 2000; O'Halloran, 1992), and leadership skills and flexibility (Brownell \& Chung, 2001; Kriegl, 2000; Nelson \& Dopson 1999; Umbriet, 1992). A study conducted by Tas (1988) in the US and subsequently replicated in the UK (Baum, 1990) and Greece (Christou, 2000) again supported the importance of the interpersonal skills, with all three studies finding that hospitality managers view the skills related to the interpersonal domain as essential.

\section{Hospitality Curriculum}

While some researchers have considered the broad needs of the hospitality curriculum in terms of skill outcomes (e.g., Baum, 1990; DiMicelli, 1998; Sigala \& Baum, 2003; Tas, 1988) others have focused on specific curriculum content issues (e.g., Breiter \& Hoart, 2000; Getty, Tas, \& Getty, 1991; Umbriet, 1992). Irrespective of the approach, there is consensus among researchers that the needs of students, industry and universities must be met through informed curriculum design (Bartlett, Upneja, \& Lubetkin, 1998) and that there is a need for continuous review and revision of the curriculum to reflect the changing needs of industry (Nelson \& Dopson, 1999).

Much of the debate relating to the hospitality curriculum has focused on the balance between applied and theoretical approaches. The importance of integration between theory and a real world perspective is supported by several researchers who have argued that the inclusion of real world experiences prepares graduates more effectively for management (DiMicelli, 1998; KelleyPatterson \& George, 2001; Sigala \& Baum, 2003). Tas (1988) argued for the inclusion of a structured internship within degree programs to provide both real world experiences and practical skills. Other researchers have identified particular aspects that need inclusion, such as leadership and skills training, services marketing, total quality management, financial analysis and communication skills (Getty et al., 1991; Umbriet, 1992) and interpersonal skills (Christou \& Karamanidis, 1999). The impact of globalisation on the hospitality industry has also been addressed with Gee (1990, as cited in Clark \& Arbel, 1993) emphasising the need for cultural sensitivity and multicultural skills. The development of information technology usage within the hospitality industry should also be recognised with there being an increased need for information technology skills to be incorporated into the curriculum (Breiter \& Hoart, 2000; Sigala \& Baum, 2003).

\section{The Generic Skills Framework}

While most of the studies described above have used a management competency model of the type described by Sandwith (1993) in analysis of graduate skill needs, this study has adopted a 
generic skills framework. The generic skills framework was developed in an educational context and has been used widely in the UK, US and Australia in curriculum analysis and design (Australian National Training Authority [ANTA], 2003). Generic skills have been described as 'those transferable skills which are essential for employability at some level' (Kearns, 2001 , p. 2). Generic skills have also been referred to as 'core skills', 'key competencies' and recently as 'employability skills' (Australian Chamber of Commerce and Industry [ACCI and BCA], 2002). The focus of the generic skills approach is on broad learning outcomes for students, rather than on the narrower management activities or competencies identified by Sandwith (1993). This broad focus acknowledges the dynamic and unpredictable nature of employment in the new millennium and the need for workers to be able to hold and continually upgrade sets of generic skills that can be transferred across different settings (Curtis \& McKenzie, 2001). It also acknowledges the role of higher education in preparing students for life and lifelong learning, rather than simply for employment.

In Australia, the publication of the 'Mayer Report' (Australian Education Council, 1992) led to substantial efforts to introduce generic skills into the curriculum of schools and the vocational education and training (VET) sector (ANTA, 2003). Recently, universities have also begun to pay explicit attention to these skills, with a number of institutions articulating these goals in the form of graduate attributes (Business/Higher Education Round Table, 2003). Griffith University in Australia has demonstrated a strong commitment to the development of generic skills through its programs (Griffith University, 2001) and this research project emerged as part of the effort to embed generic skills development into the hospitality management curriculum at this university.

A number of alternative generic skill structures have been proposed (ANTA, 2003) and this study adopted a model with nine generic skill groups similar to the employability skills framework proposed in a study by Australian industry representative groups (ACCI and BCA, 2002). A comparison of the generic skill groups used in this study with the management competency framework proposed by Sandwith (1993) is presented in Table 1. While there is substantial overlap between the two models, the generic skills framework incorporates dimensions relating to 'self-management' and the ability to adapt to different environments and undertake further learning that are not described by Sandwith (1993) but are highly relevant outcomes of an undergraduate program.

\section{Table 1}

Comparing Generic Skill and Management Competency Frameworks

\begin{tabular}{ll}
\hline A Generic Skills Framework & $\begin{array}{l}\text { Management Competency Domains } \\
\text { (Sandwith, 1993) }\end{array}$ \\
\hline Oral Communication & $\begin{array}{l}\text { Conceptual/Creative Domain } \\
\text { Leadership Domain }\end{array}$ \\
Written Communication & Interpersonal Domain \\
Problem-Solving & Administrative Domain \\
Conceptual and Analytical & Technical Domain \\
Information Management & \\
Teamwork and Leadership & \\
Interpersonal Skills & \\
Adaptability and Learning & \\
Self-Management & \\
\hline
\end{tabular}




\section{Summary}

The research into the changing role of management in the hospitality industry, graduate competency needs and the hospitality curriculum has identified the need for graduates to have a range of generic interpersonal and human relations skills, whilst technical skills were seen as comparatively less important. Research in the hospitality industry has, in the main, focused on graduates in the UK and US and no research has been undertaken in an Australian context with the exception of a study to identify the motivations of students in selecting a hospitality degree (O'Mahony et al., 2001). The research has also emphasised the changing nature of the hospitality industry and the need for a program of ongoing research to ensure the hospitality curriculum reflects industry needs, for example, in relation to information technology. Previous research has also been criticised for only seeking responses from the industry and for failing to include students in the research process. This research has also adopted the generic skills approach that is more relevant to undergraduate education than the management competencies model designed for middle and senior management.

\section{Method}

The two major aims of the study were, firstly, to apply a generic skills framework to the topic of graduate skill needs and secondly, to identify differences between hospitality managers' expectations of graduate students and undergraduate students' perceptions of what managers look for in graduate recruits. These issues were investigated by surveying samples of both populations using a self-completion survey instrument that required each group to rate the importance of a range of hospitality related skills. The skill ratings in each group were then compared in order to develop a form of expectations-perceptions 'gap analysis'.

\section{Instrument Design}

The main instrument consisted of 52 descriptions of hospitality-based activities covering the following nine generic skill areas: oral communication, written communication, problem-solving, conceptual and analytical, information management, teamwork and leadership, interpersonal, adaptability and learning, and self-management.

Skill descriptions within each of the nine domains were developed initially from a review of the literature and six focus groups of industry managers, academics and recent graduates. This process generated an initial pool of over 180 specific skill descriptions, each one relating to one of the generic skill groups listed above. An expert panel of 12 academics and industry managers assisted in condensing this item pool by identifying duplication and checking items for content validity. Finally, the draft survey instrument was refined as a result of a small pilot study using a convenience sample of industry managers.

It was essential that respondents assess the skill descriptions in the context of recruiting a person to fill a graduate traineeship position. While the pilot study and focus groups indicated that most hospitality industry managers had some understanding of these programs, a brief description of a typical graduate traineeship program was provided in the introduction to the survey for those managers who were not familiar with the concept. Following this description industry managers were asked to:

\footnotetext{
Please imagine that you are part of an interview panel involved in recruiting a university graduate to fill a graduate traineeship. How important do you think each of the following skills or qualities would be in a new recruit?
}

They were then asked to rate the importance of each skill description on a 5-point scale that was labelled $0=$ not very important to $+4=$ critically important. A don't know category was also provided so that 
respondents were not forced to rate skill descriptions that they did not understand.

The student version of the survey instrument was almost identical to that used with industry managers. They were provided with an almost identical introduction and description of a traineeship program and then asked to consider the following scenario:

Imagine that you are applying for a graduate traineeship. How important do you think each of the following skills or qualities would be to hospitality managers assessing your application?

\section{Sampling and Administration}

The sample frame for the industry survey comprised 850 general managers, human resource managers and operations managers working in 196 four- and five-star establishments with a minimum of 100 guest rooms in Australia. The sample of hospitality properties was drawn from several industry directories and is thought to comprise all such properties. Initial telephone calls were made to the human resources department of each property to identify the names of the key managers so that each survey could be personalised. The research team made follow-up telephone calls to each of the recipients one week after the initial mail out and two weeks later if no response had been received. This procedure contributed to a high industry response rate. Student perceptions were measured in a sample of 211 undergraduate students enrolled in a Bachelor of Hotel Management, a 3-year undergraduate program, using the adapted version of the instrument. The student survey was administered under controlled conditions during a lecture in a core course, thus ensuring a very high response rate.

\section{Results}

Usable responses were received from 371 industry managers (a $43.6 \%$ response rate) and responses were received from $82 \%$ of the properties targeted. A summary profile of the industry respondents is presented in
Table 2. Overall there was a good spread of managers from the various functional and operational areas and a good representation of both male and female managers. However, there was a clear, but predictable, gender bias within the functional areas with human resource (HRM) and sales and marketing ( $\& \& M)$ managers more likely to be female, whilst food and beverage $(F \& B)$ and general managers (GM) were more likely to be male. Mean age also followed an expected pattern with the operational areas of food and beverage $(\mathrm{F} \& \mathrm{~B})$ and rooms being represented by younger managers and sales and marketing (S\&M) and general management (GM) by older managers. A comparison of current age and the number of years in the hospitality industry indicates that, on average, food and beverage managers entered the industry at approximately 18 years of age while human resource managers and sales and marketing managers entered at about 22 and 27 years of age respectively. Slightly over one third of all the respondents had a university degree but this was much higher in the traditionally professional area of human resources.

In the student sample the mean age was 20 years and on average they had worked in the industry for only one and a half years. Females represented $69 \%$ of the sample and $44 \%$ of the responses came from international students.

The next section of this article describes the results of the skills rating exercise. The two populations sampled in this study had quite different socioeconomic profiles, particularly in terms of age and employment experience. A number of studies have found that individuals with different life experiences and cultural backgrounds use scales in subtly different ways (Rennie, 1982; Vasilopoulos, Reilly, \& Leaman, 2000). To minimise the impact of this type of response set on comparisons between the two groups the responses to each of the 52 items were standardised for each individual. This procedure centres each 


\section{Profile of Industry Respondents}

\begin{tabular}{lccccccc}
\hline & Total & F\&B & Rooms & HRM & S\&M & GM & Other \\
\hline Sample size & 371 & 69 & 92 & 73 & 50 & 72 & 9 \\
Gender: & & & & & & & \\
$\quad$ Male & 204 & 54 & 51 & 10 & 22 & 62 & 2 \\
$\quad$ Female & 167 & 15 & 41 & 63 & 28 & 10 & 7 \\
Age (mean) & 34.8 & 32.3 & 31.4 & 33.7 & 41.0 & 41.6 & 35 \\
Years in hospitality industry (mean) & 13.7 & 14.2 & 11.5 & 11.5 & 13.5 & 19.1 & 13.0 \\
Years with current employer (mean) & 4.3 & 3.17 & 3.86 & 3.99 & 4.10 & 6.47 & 6.0 \\
\% with university degree & $36 \%$ & $25 \%$ & $27 \%$ & $63 \%$ & $36 \%$ & $30 \%$ & $55 \%$ \\
\hline
\end{tabular}

individual's mean response to the 52 items to zero. Relative importance of a skill is indicated by a value with positive sign and relative unimportance by a value with negative sign. The following analysis uses comparisons of the ranked standardised means to compare the relative importance of skills within groups (managers or students) and comparison of the standardised mean ratings to assess the relative importance of skills between groups. Results are considered first at the individual item level then for the aggregated generic skill group.

Table 3 presents a summary of managers' top 10 and bottom 10 ranked skill descriptors and compares these to the students' responses. Analysis of the ranked skills shows that there was a substantial amount of agreement among industry managers and students about the most important skills for a graduate entering a hospitality management traineeship. Both groups identified the same skill as the most important among the 52 skill descriptors and 8 of the top 10 ranked skill descriptors were common to both groups. Skill descriptors associated with the generic skill groups of problem-solving, interpersonal skills and teamwork and leadership, featured strongly in the top 15 skills identified by both groups. It is interesting to note that neither group identified any of the activity descriptions associated with conceptual and analytical skills or information management skills among the top 20 most important skills.

Managers and students also identified the same skill descriptor as least important among the 52 items. However, the gap between industry expectations and student perceptions was generally much greater among those skills ranked outside the top 10 . Industry managers ranked 8 of the 10 activities associated with the conceptual and analytical generic skill group in the bottom 20 while students generally ranked these items substantially higher.

The group means for each generic skill domain provide a more consistent, and probably more useful to educators, indication of the types of skills managers value when recruiting trainee managers for the hospitality industry. The standardised group means are shown in Table 4 and again there is a high degree of consistency between the ranked expectations of managers and perceptions of students, with both groups identifying the same top five most important generic skill domains. Both managers and students ranked skills in the interpersonal, problem-solving, self-management, and teamwork and leadership domains as most important and skills in the information management, and conceptual and analytical domains as relatively unimportant.

Although there was little variation in the ranking of the generic skill groups between the two sample populations, 


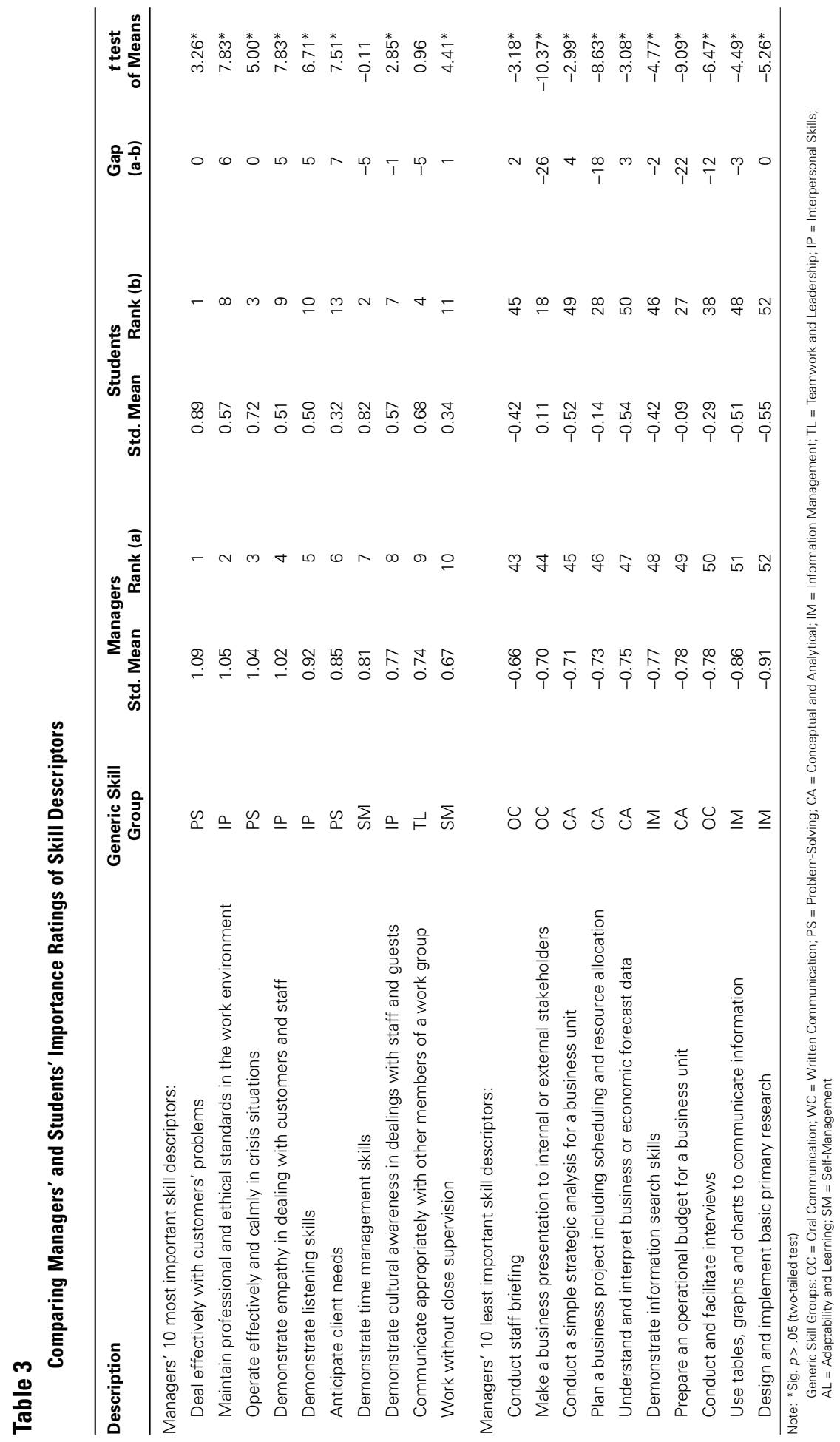


Standardised Means, Rank and $\boldsymbol{t}$ Test of Means for Each Generic Skill Group

\begin{tabular}{lccccc}
\hline & \multicolumn{2}{c}{ Managers } & \multicolumn{2}{c}{ Students } & \multirow{2}{*}{$\begin{array}{c}\text { t test of } \\
\text { Means }\end{array}$} \\
\cline { 2 - 5 } Generic skill group & Std. Mean & Rank & Std. Mean & Rank & \\
\hline Interpersonal Skills (IP) & 0.84 & 1 & 0.45 & 1 & $10.06^{*}$ \\
Problem-Solving (PS) & 0.64 & 2 & 0.36 & 2 & $7.03^{*}$ \\
Self-Management (SM) & 0.49 & 3 & 0.28 & 3 & $4.25^{*}$ \\
Teamwork and Leadership (T\&L) & 0.14 & 4 & 0.20 & 4 & -1.74 \\
Adaptability and Learning (A\&L) & 0.05 & 5 & -0.13 & 5 & $3.54^{*}$ \\
Written Communication (WC) & -0.25 & 6 & -0.20 & 7 & -0.98 \\
Oral Communication (OC) & -0.43 & 7 & -0.15 & 6 & $-6.64^{*}$ \\
Conceptual and Analytical (C\&A) & -0.46 & 8 & -0.25 & 8 & $-2.25^{*}$ \\
Information Management (IM) & -0.50 & 9 & -0.38 & 9 & $-6.57^{*}$ \\
\hline Note: *Sig. $p>$. 05 (two-tailed test) & & & & &
\end{tabular}

$t$ tests of the standardised means reveal that there were significant differences in the importance ratings of the skill groups. Managers rated interpersonal skills, problem-solving and self-management skills as significantly more important than the student group. On the other hand, students rated information management, conceptual and analytical and oral communication skills significantly more highly than did the managers.

\section{Discussion and Conclusions}

The environment in which this research was undertaken is dominated by change for both industry and higher education providers. Economic, technological and social factors are changing the nature of the hospitality manager's role and the skills they need for career success (Gilbert \& Guerrier, 1997; Umbriet, 1993). In Australia, increased access to higher education and rising student fees have created an environment where students are increasingly focused on the vocational outcomes of the programs in which they are enrolled. Ensuring that the hospitality management curriculum meets the needs of both employers and students is critical to survival of the discipline at this level.

This research applied a rigorous theoretical and administrative approach and, as a result, provides a comprehensive study of Australian managers' expectations of the skills that graduates of hospitality degree programs need to commence a career in management. The survey frame included managers at almost every four- and five-star hotel with a minimum of 100 guestrooms in Australia and responses were received from 371 managers with significant sample sizes from five functional and general management areas. The survey of industry managers was matched with a survey of undergraduates' perceptions of management expectations.

Hospitality managers identified the generic skill domains of interpersonal, problem-solving and self-management as the most important for graduates entering the industry and these results are consistent with the ranking of skill descriptors reported by Tas et al. (1996), Christou (2000) and Nelson and Dopson (1999).

The main aim of this article was to investigate the extent to which undergraduate students commencing a bachelor of hospitality management degree had realistic perceptions of the skills that managers would expect them to have on graduation. At the item level students identified 8 of the top 10 most important skill descriptors identified by managers 
and both groups identified the same bottom-ranked skill. There were some substantial differences between managers' expectations and students' perceptions of the importance of skills outside the top 10, with students tending to rank skill descriptors associated with the conceptual and analytical domain and the oral communication domain substantially higher than did the managers. When responses to the individual skill descriptors were aggregated to form group means for each generic skill there was a high degree of consistency between managers' and students' ranks of the generic skills, but managers placed significantly more emphasis, by rating the skills higher, on interpersonal, problemsolving and self-management skills than did the students.

This research makes a number of contributions to our understanding of hospitality management curriculum needs. It is the first substantial study of hospitality managers' expectations of graduate skills conducted in Australia and it is timely in relation to the rapid changes occurring in the industry and in education. The comprehensive coverage of the survey, in terms of total sample size and the range of different functional management groups surveyed, combined with the relatively high response rate suggest that the results are a reliable reflection of industry expectations. Finally, by adopting the generic skills model it has generated item responses that can be aggregated to produce more stable indicators of skill domain ratings and results that are more easily interpreted into curriculum design than the traditional management competencies model.

Some care needs to be exercised when making inferences about student expectations based on this study alone. While the industry survey sampled widely among Australian hospitality managers, the student sample was drawn from only one university program. Future research that sampled widely across hospitality programs in universities, both in Australia and overseas, would provide a valuable contribution to our understanding of student expectations. It should also be recognised that this research undertook an evaluation of perceptions of current skill needs and that these needs change over time as customer and employer expectations evolve. The challenge for designers of university curriculum is to anticipate the needs of the graduating student, since there is a considerable time lag between program design and graduate output. An alternative approach to the one used in this study would be to ask managers to forecast skill needs for the future of the industry, as opposed to reporting current needs. Future research to identify these changing expectations would be valuable in mapping trends that can be translated into contemporary curriculum design.

The results of studies, like the one described here, can make important contributions to curriculum design and the internal and external communications strategies adopted by faculty offering hospitality management programs. It is important that academics work closely with industry to educate them about the content of academic programs, build realistic expectations of graduate skills and help industry to design management traineeships that challenge participants and effectively refine management skills. Internal communications should be used early in the program to ensure that undergraduates have a clear understanding of the expectations of industry. Early intervention enables students to set realistic goals, take responsibility for their own learning and to develop skill portfolios that give them the best chance of success in their desired career.

\section{References}

Australian Chamber of Commerce and Industry, and the Business Council of Australia [ACCI and BCA]. (2002). Employability skills for the future. Canberra, Australia: Department of Education, Science and Training. 
Australian Education Council, Mayer Committee. (1992). Key competencies. Report of the Committee to Advise the Australian Education Council and Ministers of Vocational Education, Employment and Training on Employment-related Key Competencies for Post-compulsory Education and Training. Canberra, Australia: Australian Education Council and Ministers of Vocational Education, Employment and Training.

Australian National Training Authority [ANTA]. (2003). At a glance: Defining generic skills. Adelaide, Australia: National Centre for Vocational Education Research.

Bartlett, A.L., Upneja. A., \& Lubetkin, M.E. (1998). Benchmarking hospitality management curricular: A comparison of top US programs. fournal of Tourism and Hospitality Education, 10(3), 41-43.

Baum, T. (1990). Competencies for hotel management: Industry expectations of education. International fournal of Contemporary Hospitality Management, 2(4), 13-16.

Baum, T. (1991). Management trainees in the hotel industry: What do managers expect? fournal of European Industrial Training, 15(2), 3-8.

Breiter, D., \& Hoart, H. (2000). Competencies in foodservice information technology expected by the foodservice industry of graduates of hospitality bachelor's degree programs in the United States. Fournal of Tourism and Hospitality Education, 12(3), 11-17.

Brownell, J., \& Chung, B.G. (2001). The management development program: A competencybased model for preparing hospitality leaders. fournal of Management Education, 25(2), 124-145.

Business/Higher Education Round Table. (2003). Developing generic skills: Examples of best practice. Business and Higher Education Round Table News, 16(April), 1-30.

Christou, E., (2000). Revisiting competencies for hospitality management: Contemporary views of the stakeholders. Fournal of Tourism and Hospitality Education, 14(1), 25-32.

Christou, E. \& Karamanidis, I. (1999). Hospitality management competencies revisted: Industry and graduate contemporary perspectives. In A. Lockwood (Ed.), Proceedings of the Eighth Annual Council for Hospitality Management Education Hospitality Research Conference (pp. 52-68). Surrey, UK: University of Surrey.

Chung, K.Y. (2000). Hotel management curriculum reform based on required competencies of hotel employees and career success in the hotel industry. Tourism Management, 21(5), 473-487.

Clark, J.J., \& Arbel, A. (1993). Producing global managers: The need for a new academic para- digm. The Cornell Hotel and Restaurant Administration Quarterly, 34(4), 83-89.

Curtis, D., \& McKenzie, P. (2001). Employability skills for Australian industry: Literature review and framework development. Melbourne, Australia: Australian Council for Education Research.

DiMicelli, P. (1998). Blending theory and practical experience: A hands on approach to educating hospitality managers. Fournal of Tourism and Hospitality Education, 10(1), 32-36.

Dunne, E., Bennett, N., \& Carre, C. (1999). Core skills: Interpretations in higher education. In E. Dunne (Ed.), The learning society: International perspectives on core skills in higher education (pp. 63-74). London: Kogan Page.

Getty, J.M., Tas, R.E., \& Getty, R.L. (1991). Quality assessment of hotel and restaurant management graduates: Are we meeting our mission? Hospitality Research fournal, 14(2), 393-403.

Gilbert, D., \& Guerrier, Y. (1997). UK Hospitality managers past and present. The Services Industries fournal, 17(1), 115-132.

Griffith University. (2001). Strategic Plan 2001-2005: Teaching and Learning. Retrieved April 1, 2002, from http://www.gu.edu.au/ua/aa/sp/sp/ content/TaL.html

Kandampully, J., \& Suhartanto, D. (2000). Customer loyalty in the hotel industry: The role of the customer satisfaction and image. International Fournal of Contemporary Hospitality Management, 12(6), 346-351.

Kay, C., \& Russette, J. (2000). Hospitality management competencies: Identifying managers' essential skills. The Cornell Hotel and Restaurant Administration Quarterly, 41(2), 52-63.

Kelley-Patterson, D., \& George, C. (2001). Securing graduate commitment: An exploration of the comparative expectations of placement students, graduate recruits and human resource managers within the hospitality, leisure and tourism industries. International fournal of Hospitality Management, 20(4), 311-323.

Kearns, P. (2001). Generic skills for the new economy. $A$ review of research relating to generic skills. Adelaide, Australia: National Centre for Vocational Education Research.

Knutson, B.J., \& Patton, M.E. (1992). How prepared am I to succeed in the hospitality industry? What the students are telling us. Hospitality and Tourism Educator, 4(3), 38-43.

Kriegl, U. (2000). International hospitality management. Identifying important skills and effective training. The Cornell Hotel and Restaurant Administration Quarterly, 41(2), 64-71.

Nelson, A.A., \& Dopson, L. (1999). Future of hotel education: Required skills and knowledge for graduates of U.S. hospitality programs beyond 
the year 2000-Part one. Fournal of Tourism and Hospitality Education, 13(5), 58-67.

Okeiyi, E., Finley, D., \& Postel, R.T. (1994). Food and beverage management competencies: Educator, industry and student perspectives. Hospitality and Tourism Educator, 6(4), 37-40.

O'Halloran, R.M. (1992). Tourism Management profiles: Implications for tourism education. Florida International University Hospitality Review, 10(1), 83-91.

O'Mahony, G.B., McWilliams, A.M., \& Whitelaw, P.A. (2001). Why students choose a hospitality degree program. The Cornell Hotel and Restaurant Administration Quarterly, 42(1), 92-96.

Perdue, J., Woods, R.H., \& Ninemeier, J. (2000). Club management competencies 2005: Updated information for the classroom. Fournal of Tourism and Hospitality Education, 14(2), 19-32.

Purcell, K., \& Quinn, J. (1996). Exploring the education-employment equation in hospitality management: A comparison of graduates and HNDs. International fournal of Hospitality Management, 15(1), 51-68.

Rennie, L.J. (1982). Research note: Detecting a response set to Likert-type attitude items with the rating model. Education Research and Perspectives, 9(1), 114-118.

Sandwith, P. (1993). A hierarchy of management training requirements: The competency domain model. Public Personnel Management, 22(1), 43-62.

Sigala, M., \& Baum, T. (2003). Trends and issues in tourism and hospitality higher education: Visioning the future. Tourism and Hospitality Research, 4(4), 367-376.

Tas, R.E., LaBrecque, S.V., \& Clayton, H.R. (1996). Property-management competencies for management trainees. The Cornell Hotel and Restaurant Administration Quarterly, 37(4), 90-96.

Tas, R.F. (1988). Teaching future managers. The Cornell Hotel and Restaurant Administration Quarterly, 29(2), 41-43.

Umbreit, W.T. (1992). In search of hospitality curriculum relevance for the 1990s. Hospitality and Tourism Educator, 5(1), 71-74.

Umbreit, W.T. (1993). Essential skills: What graduates need to succeed. Hosteur, 3(1), 10-12.

Vasilopoulos, N.L, Reilly, R.R., \& Leaman, J.A. (2000). The influence of job familiarity and impression management on self-report measure scale scores and response latencies. Fournal of Applied Psychology, 85(1), 50-64.

Whitston, K. (1998). Key skills and curriculum reform. Studies in Higher Education, 23(3), 307-319. 